\title{
等電位型抵抗分圧器の ステップ応答シミュレーション
}

\author{
正員里 周二 (宇都宮大学) \\ 学生員 高田 文洋 (宇都宮大学) \\ $\begin{array}{lll}\text { 正員 } & \text { 原田 達哉 } & \text { (日本工業大学) } \\ \text { 正員 } & \text { 脇本 } \text { 隆之 } & \text { (日本工業大学) }\end{array}$
}

The Numerical Unit Step Response Simulation of The Equi-Potential Type Resistive Divider

SATO Shuji, Member (Utsunomiya University); HARADA Tatsuya, Member (Nippon Institute of Technology); TAKADA Fumihiro, Student Member (Utsunomiya University); WAKIMOTO Takayuki, Member (Nippon Institute of Technology)

In the paper, a possibility of the unit step response simulation in a time domain from the resistive divider's dimensions is discussed. This technique consists of two stages: to compute the floating capacitances between the segmented two electrodes as well as stray capacitances to the ground; and to calculate the unit step response for the constructed equivalent circuit using EMTP. To verify the validity of the proposed simulation, a 200kV equi-potential resistive reference divider is to be selected. This is because the equi-potential divider's unit step response can theoretically be estimate. The numerical simulation has been in completely agreement with the expected response. The results showed a possibility that even without constructing prototype dividers, one can determine divider's dimensions which yield the best step response.

キーワード：抵抗分圧器、等電位型分圧器、浮遊静電容量計算、EMTP、IEC-60

\section{1. まえがき}

1994 年、IEC 60 がほぼ 20 年振りに改訂され、電気試 験の認定基準を IEC に準拠する国々ではインパルス電圧 測定に対して、基準分圧器を所有し、これによって日常使 われる分压器を定期的に校正する必要のあることが盛り 込まれた (1)。この基準分圧器はステップ応答に関する IEC の要求を満たすものでなくてはならない。

一般にインパルス電圧測定用分圧器の開発は以下のよ うな手順に従って行われる。まず、分圧器の定格電压、測 定波形が定められると気中絶縁強度を考慮して分区器の 高さが決定される。このあと、これまでのやり方は、定め られた高さの制約の下に高圧シールドを始めとする各部 の寸法、形状を「試行錯誤で様々に変化させて」ステップ 㐫答が IEC の要求する数值の中になる心゙く裕度をもつて 収まるよう定めるといったものであった。

このとき使われる分圧器モデルはプロトタイプと呼ば れ、最終製品として製作される分圧器の原形となるもので ある。但し、ブロトタイプ分圧器はステップ応答特性を測 定し、データを収集することにだけに主眼が置かれたもの
であるため、絶縁特性、機械的強度などには殆ど注意が払 われていない。プロトタイプ分圧器の形状決定過程では例 えば、高压側シールドリングの位置に関しては、異なった 高さでステップ電圧を印加し、応答を観測して最適位置を 決定する。プロトタイプで定められた形状を基に実際の分 压器が製作され、完成後改めてステップ応答特性、耐压、 コロナ等の試験が行われる。

現在の分圧器製作上の問題はプロトタイプ分圧器を用 いての形状决定過程にあると考えられる。例えば、前述の ように高圧側シールドリングの最適位置を精度良く定め ることは可能であるが、シールドリングの断面径、外周径 を小刻みに变えて多数の組み合わせの中から最適値を得 るためには、各種のシールドリングを準備しなければなら ない。また、1台のプロトタイプ分圧器を用いて数多くの 条件についてステップ応答を測定することは多大の時間 を消費する。

もし何らかの方法でこのプロトタイプの試験過程を精 度良いコンピュータシミュレーションで置き換えること ができるなら、分圧器開発に要する時間が大幅に短縮され る(複数のコンピュータで異なった条件を計算させれれ゙更 に短縮される）のみならず、プロトタイプの限られた数の 
ばならない。また、1台のプロトタイプ分圧器を用いて数 多くの条件についてステップ応答を測定することは多大 の時間を消費する。

もし何らかの方法でこのプロトタイプの試験過程を精 度良いコンピュータシミュレーションで置き換えること ができるなら、分圧器開発に要する時間が大幅に短縮さ れる(複数のコンピュータで異なった条件を計算させれ ば更に短縮される）のみならず、プロトタイプの限られ た数の形状では網羅できない条件についての応答特性も 評価でき、より高性能の分圧器の製作が可能となる(访-(7)。 分圧器の数值シミュレーションはこれまで全くない訳で はなかったが、計算の困難さのためか、電極間静電容量 を無視したり (2-3)、主抵抗全体を一個の電極とみなして静 電容量を計算し、 $\mathrm{n}$ 分割された電極の対地静電容量を単 純に $1 / \mathrm{n}$ として求めたり、潾り合う電極間の静電容量を 一定と仮定する(4)など、大幅な簡略化を導入したもので、 いずれも大胆な近似が行われており、分圧器の電気回路 的な構成要素を正確に考慮したものではなかった。

本論文では従来の簡単なシミュレーションに代わって、 表面電荷法に基づく電界解析で抵抗分圧器の寄生静電容 量を精度よく計算し、時間領域であるステップ応答特性 まで机上で求めることの可能性について述べたものであ る。本論文では、提案した計算方法の妥当性を確認する ため、200kV 等電位型抵抗分圧器のシミュレーションを行 い、計算された波形と理論的に予想される応答波形との 比較を行い、シミュレーションが理論と極めて精度良い 一致を示すことを示す。

本文では以下、特に断らない限り、「分圧器」とは「抵 抗型雷インパルス分圧器」を、「応答特性」や「ステッ ブ応答」とは「ユニットステップ応答特性」を意味する。

\section{2. 分圧器モテル}

高電圧分圧器は文字通り高電圧を分圧するものである から、印加された高電压の絶縁は気中で行うため、定格 電圧が上がるとともに高圧電極は大型となり、かつ地上 高は必然的に高くなる。

この結果、寄生の静電容量（長さのディメンジョンに 比例する）は段々と無視できなくなる。つまり、リード 線の影響を無視し、かつ入力波形が完全なステップ電圧 であっても、低圧部からの出力波形は、この寄生の静電 容量と主抵抗のなす時間遅饥のため、かなり鈍った波形 となって測定される。この寄生の静電容量の様子を図 1 に示す。図では分圧器主抵抗部を、要素内で電位が一定
とみなせるまで $\mathrm{n}$ 個の微小な要素（電極）に分割し、電 極間静電容量、対地静電容量に類別して表示している。

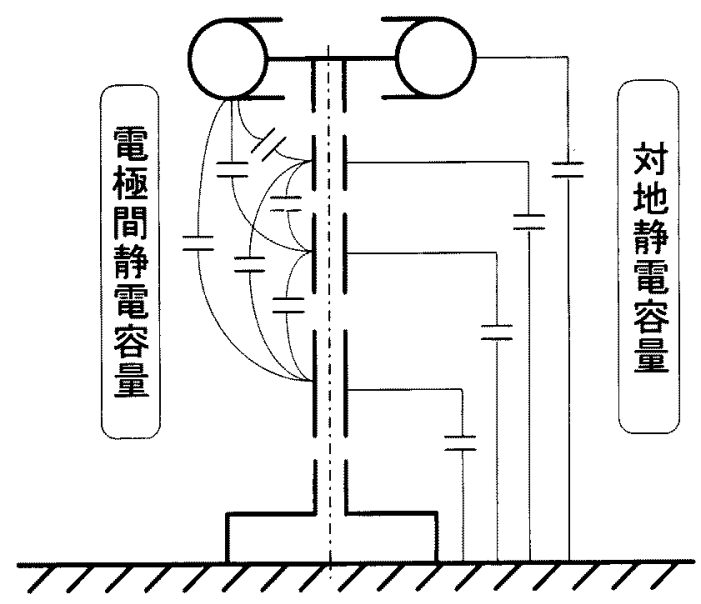

図 1 分圧器と寄生の静電容量

Fig. 1 Divider and floating capacitances

この図の等価回路を描いたものが図 2 である。

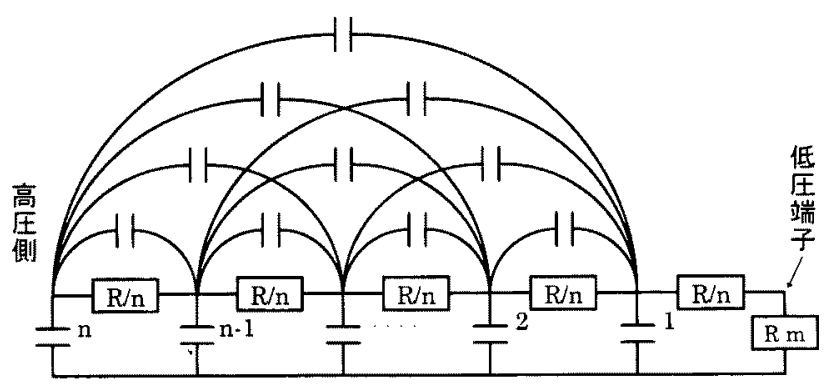

図2抵抗分圧器の等価回路

Fig. 2 Equivalent circuit of resistive divider

図中に描かれたすべての静電容量さえ何らかの方法で正 しく計算されると、図中に示される低圧部抵抗 $R_{m}$ から取 り出されるステップ応答波形は、たとえ高圧部にリード 線などの外付けの素子がつながれた場合でも、EMTPなど の過渡現象解析プログラムによって計算できる。つまり、 分圧器を実際に組み立てることなく、分圧器の形状、寸 法及び分圧器を構成する抵抗、リード線だけから机上で 分圧器の応答特性を計算できることになる。 


\section{3. 静電容量の計算方法}

いま、図3に示されるように一様な絶縁媒質中に $\mathrm{n}$ 個 の電極があるとき、簡単のため各電極面上で電荷密度 $\sigma_{,},(j=1 \sim n)$ が二定であると仮定すると、電極電位 $\phi_{i},(i=1 \sim n)$ は電位保数 $P_{i j}$ を使って、

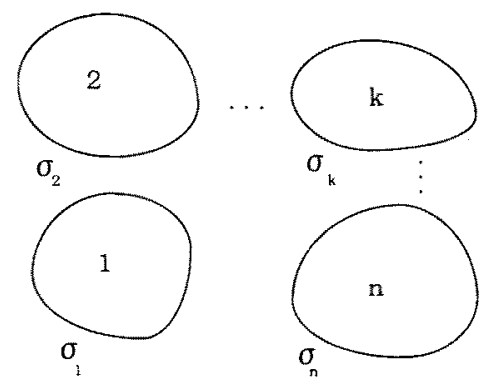

図 $3 \mathrm{n}$ 個 $の$ 電極

Fig. 3 n electrodes

$$
\left(\begin{array}{ccc}
P_{11} & \cdots & P_{1 n} \\
\vdots & \ddots & \vdots \\
P_{n 1} & \cdots & P_{n n}
\end{array}\right)\left(\begin{array}{c}
\sigma_{1} \\
\vdots \\
\sigma_{n}
\end{array}\right)=\left(\begin{array}{c}
\phi_{1} \\
\vdots \\
\phi_{n}
\end{array}\right)
$$

とあらわされる。(1)式において、電位倸数 $P_{i j}$ は電極（電 荷）形状及び電極を代表する点（表面電荷法では輪郭点 と呼ばれる）が与えられれば一意的に計算される量であ る。また、電位 静電容量計算では具体的な数值を与えない。(1)式を $(\sigma)$ について解くと、次式を得る。

$$
\left(\begin{array}{c}
\sigma_{1} \\
\vdots \\
\sigma_{n}
\end{array}\right)=\left(\begin{array}{ccc}
k_{11} & \cdots & k_{1 n} \\
\vdots & \ddots & \vdots \\
k_{n 1} & \cdots & k_{n n}
\end{array}\right)\left(\begin{array}{c}
\phi_{1} \\
\vdots \\
\phi_{n}
\end{array}\right)
$$

上式は表面電荷法による電界計算(8)のとき使われる式と 全く同じものである。

各電極面上の電荷量を $Q_{j},(j=1 \sim n)$ 、その面積を $s_{j},(j=1 \sim n)$ とすれば、次のマトリックスを得る。

$$
\left(\begin{array}{c}
Q_{1} \\
\vdots \\
Q_{n}
\end{array}\right)=\left(\begin{array}{ccc}
s_{1} & & 0 \\
& \ddots & \\
0 & & s_{n}
\end{array}\right)\left(\begin{array}{c}
\sigma_{1} \\
\vdots \\
\sigma_{n}
\end{array}\right)
$$

（3）式に(2)式を代入すれば次式を得る。

$$
\left(\begin{array}{c}
Q_{1} \\
\vdots \\
Q_{n}
\end{array}\right)=\left(\begin{array}{ccc}
s_{1} k_{11} & \cdots & s_{1} k_{1 n} \\
\vdots & \ddots & \vdots \\
s_{n} k_{n 1} & \cdots & s_{n} k_{n n}
\end{array}\right)\left(\begin{array}{c}
\phi_{1} \\
\vdots \\
\phi_{n}
\end{array}\right)=\left(\begin{array}{ccc}
K_{11} & \cdots & K_{1 n} \\
\vdots & \ddots & \vdots \\
K_{n 1} & \cdots & K_{n n}
\end{array}\right)\left(\begin{array}{c}
\phi_{1} \\
\vdots \\
\phi_{n}
\end{array}\right)
$$

$$
\text { 但し、ここに } K_{i j}=s_{i} k_{i j} \text { とする。 }
$$

上式の i 行目は、

$$
\begin{aligned}
Q_{i} & =\left(K_{i 1}+\cdots+K_{i n}\right) \phi_{i}-K_{i 1}\left(\phi_{i}-\phi_{1}\right)-\cdots-K_{i n}\left(\phi_{i}-\phi_{n}\right) \\
& =C_{s i} \phi_{i}+C_{n}\left(\phi_{i}-\phi_{1}\right)+\cdots+C_{i n}\left(\phi_{i}-\phi_{n}\right)
\end{aligned}
$$

とかけるので、周囲の媒貿が一様であれば電気磁気学の 定義により、 $\mathrm{i}$ 番目の電極の対地静電容量 $C_{s i}$ は、

$$
C_{s i}=\sum_{j=1}^{n} K_{i j}>0
$$

$\mathrm{i}$ 番目と $\mathrm{j}$ 番目の電極間の静電容量 $C_{i j}$ は、

$$
C_{i j}=C_{j}=-K_{i j}=-K_{j i}>0
$$

と計算される ${ }^{(9)}$ 。

分压器では、架台や低圧シールドボックスなどの近接 接地物体の影響を加味した静電容量の計算が必要となる ことが多い。上で述べた電極モデルで、例えば簡単のた め 1 番目の電位が接地されているものとすれば、2〜n 番 目の電極の対地静電容量 $C_{\mathrm{s} j}^{\prime}$ は、

$$
C_{s j}^{\prime}=C_{s j}+C_{1 j} \quad(j=2 \sim n)
$$

で計算できる。但し、ここにC れていないときの $\mathrm{j}$ 番目の電極の対地静電容量、 $C_{1 j}$ は 1 番目の電極とj番目の電極の間の静電容量である。近接 接地物体の有無にかかわらず電極間静電容量に変化はな W。

以上は浮遊容量の計算の概念を極めて簡略化したモデ ルを使って定式化したが、実際の数值計算ではこの説明 で 1 個と数えられた電極は更に微小な同電位の構成要素 に分割され、この微小な要素上でも電荷密度は最低 3 次 の直交多項式で展開され、計算が行われる。このとき、

(4)式にあらわれるマトリックスの要素は実はサブマト リックスとなり、（5）式の $K_{i j}$ に関する和はサブマトリッ クス要素の和となる。 


\section{4. $200 k \mathrm{~V}$ 等電位型分圧器}

一般に抵抗分圧器を $\mathrm{n}$ 個の電極の集合とみなすと、分 压器は図 2 に示される等価回路で記述される。この等価 回路において、高圧側（図の左側）からステップ電圧を 印加すると、簡単な電気回路の知識から以下のような過 渡現象が生じていることが理解されよう。

(1) $t=0$ では各部の電位（節点電位）は浮遊容量による C-Cカッブリングで定められる。

(2) $t=\infty$ では入力のステップ電压は直流成分のみとなっ ているので、各部の電位は容量分を無視した単純な抵 抗分圧で決まる。

$t=0 \sim \infty の$ 間がいわゆる分圧器の単位ステップ応答特性 と呼ばれるものである。

ところが、何らかの方法で $t=0$ における各部の電位分 布を $t=\infty$ での電位分布と同じくすることが可能なら、実 質的な過渡応答はなくなるので理想的な分圧器が実現で きるはずである。この考えに基づいた分圧器を等電位型 分圧器と呼び、200kV 級のものが試作されている(7)。

分圧器の抵抗值は高圧部が $3382 \Omega$ 、低圧部が $4.872 \Omega$ 、 主抵抗部の長さは $555 \mathrm{~mm}$ 、高圧シールド断面径が $\phi 100 \mathrm{~mm}$ 、 シールドの中心径が $\phi 250 \mathrm{~mm}$ 、架台（電気的には近接接地 物体とみなす）は $190 \mathrm{~mm} \times 190 \mathrm{~mm}$ 、高さ70 mm の箱である。

図 4 に電界計算プログラムを使って計算されたメイン カラム部に沿った電位分布から、微小電極の位置を計算 する方法を示す（例では、50\%電位に相当するメインカラ ム上の位置を求めている)。

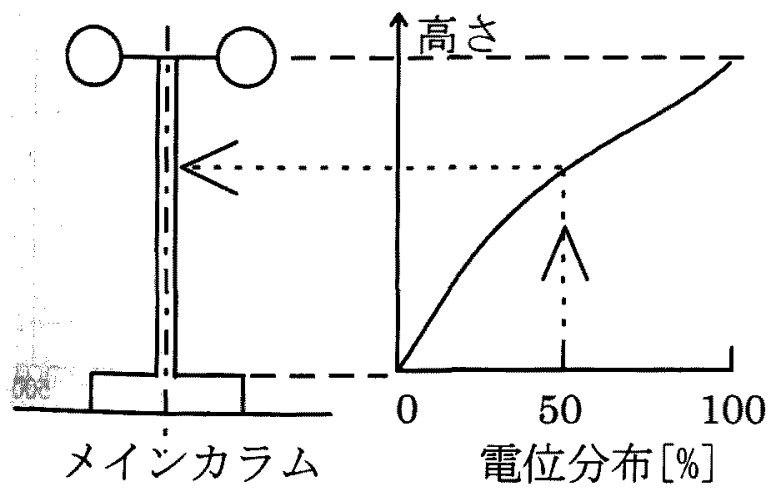

図 4 等電位型分压器の抵抗巻線の決定方法

Fig. 4 Determination of winding pitch for the equipotential divider
0〜100\%まで 10\%おきに、金属線抵抗体が巻かれた円筒部 を半径とする大きさの暴なる厚さのない円筒状の電極 (ただし、0\%電位の電極は架台を含み、100\%電位の電極 はシールドリングを含む。具体的な様子は後揭の図 5 参 照）を 11 個つくると、各電極の電位は図 2 の等価回路の C-C 分圧で決まる電位となっているはずである。これによ り、 $t=0$ での電位分布を均一に定めることができ、上記 の(1)の条件が满足される。

次に、電界計算から決定された 0〜 10\%、10〜20\%、... $90 \sim 100 \%$ 電位に相当するメインカラムの区間に主抵抗の ちょうど10分の1に等しい抵抗を巻く（各区間では等ビ ッチで巻かれるので、長い区間上でのピッチは粗くな る）と抵抗分圧による各等電位電極の電位分布は均一に なる、すなわち $t=\infty$ における電位分布は前述の(2)の条 件を満たす。以上から初期に意図した通り、 $t=0$ での電 位分布と $t=\infty$ での電位分布を等しくすることができる。

最下部の大地電位を持つ電極を除く等価電極を、下か ら順に $1,2, \cdots, 10$ と番号を付け（10 番目の電極はリング シールドを含んだ高圧側電極となることに注意）、各等 価電極間の静電容量を数值計算し、有效数字 4 析のみ記 したものが表 1 の值である。隣り合う等価電極の間には 主抵抗を10等分した $338.2 \Omega$ の抵抗がつながれている。

単純に静電容量を計算すると、隣り合う等価電極は接 しているので電極間静電容量は無限大となり、不都合が 生じるので電極の大きさを長手方向にのみ縮めた。縮小 の割合（係数）を様々に変化させたが、70〜90\%の間で は計算された応答波形に殆ど変化がなかったので、以後 計算では 80\%を採用した。ただし、80\%が決定的な值とい うことではなく、「極めて緩やかなカーブを描き、80\%付 近で最適值を示す。」といった程度のことである。

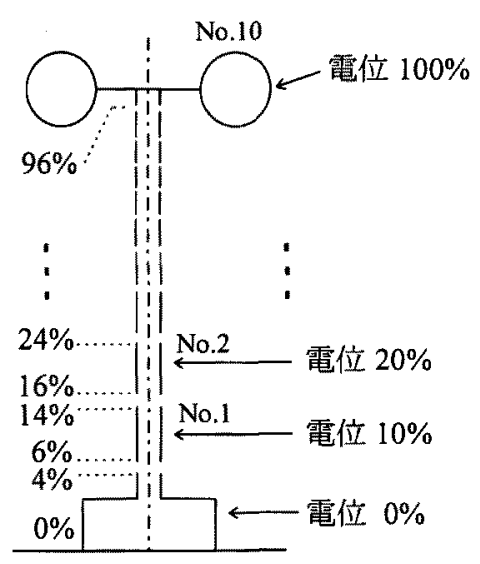

図 5 メインカラムの分割(縮小係数 $80 \%$ )

Fig. 5 Division of the main column (scale factor $80 \%$ ) 


\section{表 1 等電位型分压器 $(n=10)$ の静電容量の值}

Table 1 Computed capacitances of the equi-potential divider $(n=10)$

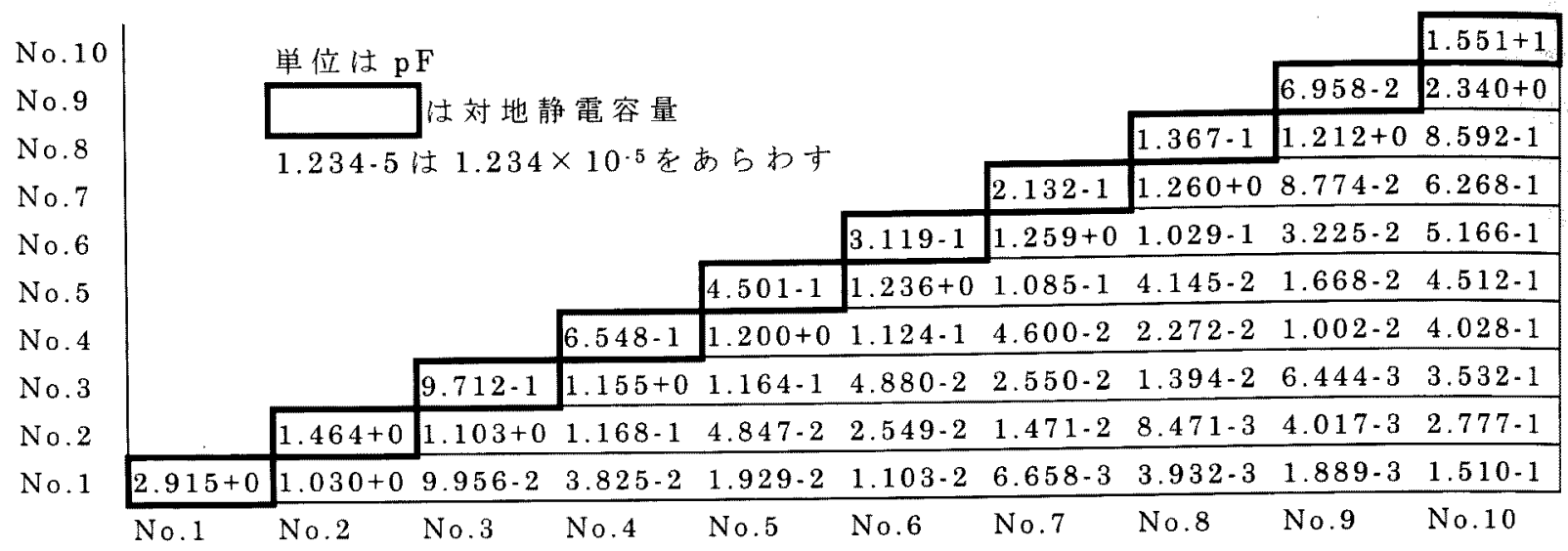

実際、85\%の縮小倸数を用いたとしても、ステップ応答波 形の違いはグラフに描かれた線の太さほどもないので、目 視観測からはまったく識別できない。

例えば縮小係数 $80 \%$ のと、主抵抗部は図 5 に示すよう に、電位0の架台を含め11 個の小電極に分割することを 考える。

口 電位 $0 \%$ 接地電極はメインカラムに沿って電位分 布 0 〜 $5 \%$ を方に $80 \%$ に縮めた電位 0 〜 $4 \%$ に相当す る部分。

$\square$ 電位 $10 \%$ の No. 1 電極は電位分布 5 〜 $15 \%$ を下方向 に $80 \%$ 縮めた電位 6 ～14\%に相当する部分。

口 以下、次々と電位 $90 \%$ に相当する電極まで同様に定 義する。

$\square$ 最後の電位 $100 \%$ No. 10 電極は電位分布 $95 \sim 100 \%$ を上方に $80 \%$ に縮めた電位 96 〜 $00 \%$ に相当寸る部 分で代表する。

静電容量の計算では架台は近接接地物体として取り扱わ れ、No.10の高压電極はリングシールド電極の一部とし て取り扱われる。図2 の等価回路と浮遊容量を計算した表 1 の值からEMTPにより計算したステップ応答を図 6 に、電圧印加直後（シミュレーションでは $0.5 \mathrm{ps}$ 後）の各 部の分担電圧 $(\%)$ を表 2 に示す。

表 2 各電極の分担電压 (unit: \%)

Table 2 Distributed voltage at each electrode

\begin{tabular}{|ccccc|}
\hline No. 1 & No. 2 & No.3 & No. 4 & No. 5 \\
10.007 & 20.001 & 29.998 & 39.9834 & 49.965 \\
\hline No. 6 & No. 7 & No. 8 & No. 9 & No. 10 \\
59.966 & 69.991 & 80.048 & 90.092 & 高圧入力 \\
\hline
\end{tabular}

計算では提案するシミュレーションモデル及び方法の 妥当性を検証する目的から、リード線や測定ケーブルは考 慮されていない。図6の時間軸の最大は500psであり、こ のように時間領域を拡大しても応答波形は期待した通り 殆ど入力波形に近く、理論的に予想される「過渡状態がな い分圧器であることが数值計算で確認できる。図6のグ ラフの初期応答時間を計算することも可能であるが、実際 の測定で用いられるステップジェネレータの立ち上がり 時間、数百 ps、に比べてはるかに小さいのでここでは行 わなかった。また表 2 に示される值から、計算されたC-C 分圧で決まる各部の分担電压も目標值に極めて近いこと が判る。これらの結果から、本論文で提案した浮遊静電容 量計算アルゴリズムから等洒回路にいたるシミュレーシ ヨン手法の妥当性及び精度が確認されたと言えよう。

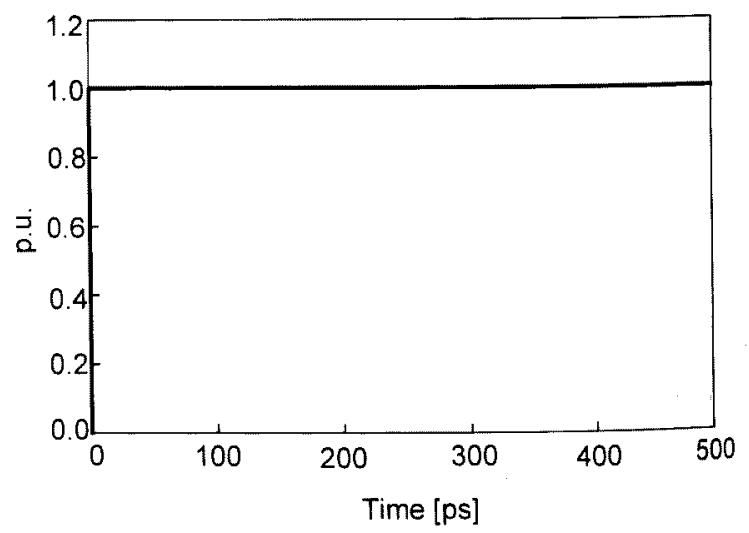

図 6 等電位型分圧器のユニットステップ応答

Fig. 6 Equi-potential divider's step response 
Kaane 氏は高電圧分圧器の数值シミュレーションにお いて「浮遊容量のうち対地間静電容量のみ考慮する」こと の重要さをのべている(3)。この妥当性を検証したものが図 7 に示すステップ応答である。この図は表 1 に示される数 值のうち太い枠内に記された数值対地間静電容量と主抵 抗から等価回路を構成し、EMTPによりシミュレーショ ソしたものである。図7の時間軸の最大は図6の100 倍で ある50nsであることに注意されたい。この時の初期応答 時間 $T_{\alpha}$ は約 $3.8 \mathrm{~ns}$ であった。

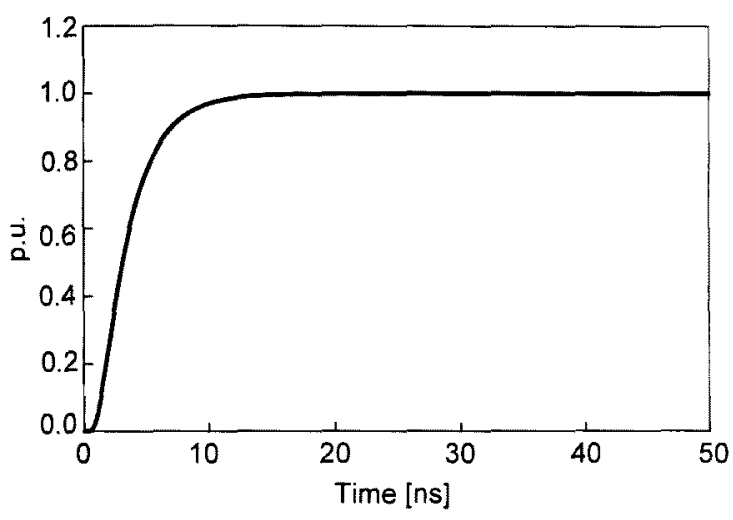

図 7 簡易回路を用いた等電位型分圧器のユニットステッ フ応答

Fig. 7 Equi-potential divider's step response using simplified model

この值は電極間静電容量を無視したことによる応答時間 の誤差と考えられ、筆者らのモデルで得られた「限りなく 零に近い值に比べるとかなり大きな誤差であり、筆者ら のシミュレーション精度に遠く及ばず、電極間静電容量を 考慮することが不可欠であることを示している。

\section{5. まとめ}

理諭的な応答波形が判っている等電位型分圧器を例に とって、200k V分圧器のステップ応答特性の数值シミュ レーションを行ったが、計算された波形は予測值と極めて 良好な一致を見た。このことにより、筆者らの提案する静 電容量の数值計算方法及び分圧器のシミュレーション方 法の妥当性及び精度が確認できたのみならず、将来の標準 分圧器の開発はプロトタイプ分圧器を用いたパラメータ 決定の過程を経ることなく、CAD的な手法でコンピュー タ上で高速に、かつ極めて精度良く決定できることが明ら かになった。また、本論文で初めて取り上げた電極間静電 容量を考慮した分压器等価回路が精度良いシミユレーシ
ヨンには不可欠であることが確認できた。

\section{6. 謝 辞}

本研究を行らにあたり、200 k V 等電位型分圧器の形状 決定についての詳細な情報及び助言を寄せながら、自らの 貢献を小とし著者に加わらなかった、スイス連邦理工科大 学 (ETH)、Zürich High Voltage Group $の$ W.S.Zaengl 教授に深く感謝の意を表します。

(平成8年9月30日受付、同年11月19日再受付)

\section{参考文献}

(1) IEC 60-2: "High Voltage Testing Technique, Measuring Systems", 1994, Geneve

(2) D.Peter et al.: "Resistive Voltage Divider for 1MV Switching and Lightning Voltages", ISH'87, Vol.3, 1987, Braunschweig

(3) H.L.Kaane: "A Simple Method for the Transient Analysis of High Voltage Dividers based on Analytical Calculation of Stray Capacitance", ISH'91, Vol,6, 1991, Dresden

(4) Y.Kawaguchi et al.: "Unit Step Response Simulation of Impulse Voltage Measuring System by EMTP”, ISH'93, Vol.2, 1993, Yokohama

(5) T.Harada et al.: "Development of Reference and Ceramic Dividers in Japan", ISH'95, Vol.4, 1995, Graz

(6) 里 周二他: “抵抗型高電圧分圧器の数值応答解析”、 No. 1649、平成 7 年電気学会全国大会

(7) S.SATO et al.: "Digital Step Response Analyses of Resistive Impulse Voltage Dividers", ISH'95, Vol.4, 1995, Graz

（8）里 周二他：“高速表面電荷法”、電気学会論文誌、 Vol.101A, No.9, pp.455-462, 1981

（9）電気学会通信教育会: “電気磁気学 (改訂版6 版)”、 pp.61-83, 1968、電気学会発行 


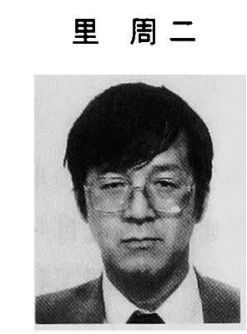

(正員) 1950 年生まれ。'75 年九州大学大 学院修士課程修了。同年東京芝浦電気(現 東芝)入社。'82 年同社退社後スイス理工 科大学勤務。この間同大学より工学博士を 授与される。同大学を経て'89 年より宇都宮 大学助教授。この間主として、表面電荷法 による数值電界解析、EMTPを用いた過渡 現象解析、基準インパルス分圧器の開発の 研究に従事。

原田達哉

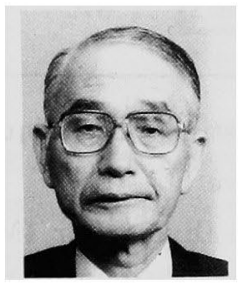

(正員) 1924 年生まれ。'52 年東京工業 大学大学院特別研究生修了。電力中央研 究所、佐賀大学理工学部教授、日本工業 大学教授を経て現在同大学客員教授。工 学博士。IEEE フェロー。'66 年電気学会 論文賞、'68、'71、'72 年同進歩賞、'75 年同電力賞、'94 年同著作賞、科学技術 庁長官賞 (科学技術功労者)受賞。'70、 71 年東京支部会計幹事、'70、71 年編 集理事。高電圧·電流試験、放電現象、イ ンパルス電圧・電流測定などの研究に従 事。現在高電圧試験標準特別委員会及び インパルス基準測定システム委員会各委 員長。

高田 文洋 （学生員）1972 年生まれ。'95年宇都宮大

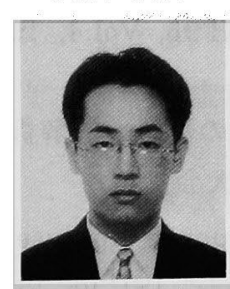
学卒業。同年、同大大学院進学。標準分圧 器の応答特性解析の研究に従事。現在に いたる。

脇本 隆之

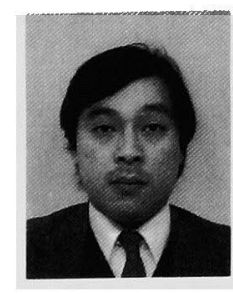

(正員) 1964 年生まれ。'89年佐賀大学大 学院理工学研究科電気工学専攻修士課程 修了。同年佐賀県立有田工業高等学校電 気工学科教諭、吳工業高等専門学校助手 を経て現在日本工業大学超高圧放電研究 センター助手。主としてインパルス電圧・電 流のディジタル測定に関する研究に従事。 